\title{
Sustainable Livestock Farming for Improving Socio-Economic Condition
}

\author{
Mohammad Shamsuddoha ${ }^{*}$, Mohammed Quaddus ${ }^{1}$, Desmond Klass ${ }^{1}$
}

\begin{abstract}
Sustainability is the most effective concept to improve socio-economic condition, including environment. Constructive socio-economic changes are getting priority in recent years among academia and business sector in Bangladesh. Bangladesh poultry sub-sector has long supply chains having associated with various stakeholders. In this paper, a case poultry farm was taken to examine a production process that links with socio-economic benefits. Design science method under the quantitative paradigm was chosen to develop a model for the case industry. A Simulation model was developed using simul8 software to construct the real poultry operation. The objectives of this paper are to construct a sustainable model for a case poultry industry along with socio-economic issues. Later, simulated model output will examine it through various performance indicators (KPIs) to find out the impacts on socio-economic benefits. Numbers of KPIs have been briefly discussed in light of the research problem to illustrate positive effects of sustainable production.
\end{abstract}

Keywords: Sustainability, supply chain, reverse chain, socio-economic challenge.

\section{Introduction}

Poultry is one of the major hidden sub-sectors, which is contributing inexhaustible way to its economy for the reputation of self-employment opportunities, cheap sources of protein supply, and income sources for millions of people. Bangladesh has about 120,000 - 130,000 poultry farms of all sizes - small, medium and large - with a total investment of around US $\$ 2$ billion. According to International Finance Corporation (IFC), around 2 billion chickens in Bangladesh generate some 22 million tons of manure a year (ThePoultrySite [38]). Subsequently, this industry failed to adapt modern technology for poultry procurement and processing along with sustainability issue. As a result, this industry is damaging sound surround environment, which is very essential for over populated country like Bangladesh. Sustainability and environment (Corbett and Kleindorfer [7]) are getting relative importance due to its direct influence on achieving competitiveness in the local and global arena. In this situation, it is vigorous to associate sustainability and supply chain concepts within their existing production and procurement. Now poultry needs a structured supply chain model that must be combined with sustainability, dynamic supply chain processes like reverse and forward chains, environmental issues, and profitability and optimality concepts. The practical contribution of this study was to identify various benefits derived from sustainable poultry operations.

$1^{1^{*}}$ Graduate School of Business, Curtin University, 78 Murray Street, Perth WA 6000, Australia. Email: mdsdoha@gmail.com, Mohammed.Quaddus@gsb.curtin.edu.au, Des.Klass@gsb.curtin. edu.au

" Corresponding author
The simulation study helped to measure these benefits in light of number of poultry birds reared.

Policy makers or decision makers can give desired input to the simulation model to get instant result to justify the outputs. Acceptance or refusal of simulated results depends on its impact over society.

The objectives of this study are as follows: (1) To discuss about existing input-output poultry sustainable poultry process model. (2) To develop a simulation model of sustainable poultry production process for mitigating socioeconomic challenge. (3) To review simulated Key Performance Indicators (KPIs) to find out optimal consequence on socioeconomic condition.

\section{Methods}

This study covers a literature review on environmental sustainability, reverse supply chain and Bangladesh poultry industry. The study also adopted a positivist ontology, empirical epistemology and quantitative methodology based on case studies of a real poultry supply chain. The design science methodology and case study method chosen for this study. Design science is concerned with "devising artefacts to attain goals (Simon [35]). Design science is based on "build and evaluate" an artefact of a model (March and Smith,[18]. Here, an artefact means designing and develop soft or hard objects that can meet specific purposes and goals (Venable [39,40]). On the other hand, Case studies are observed descriptions of a particular instance of an occurrence (Yin [42]). Both primary and secondary information have used in this study. The research designed was followed system and system dynamic research since 
1990s. For effective research design, this study completed the step of the system concept building, identify key variables, developing mental or soft or causal model, construct a quantitative model, set the appropriate formulas for key variables, and check the validity and reliability and policy implementation.

Primary information has collected from January 2012 to August 2012, mainly through in-depth telephone interviews. This paper used in-depth interviews and observation tools to gain insights supply chain processes to understand and develop a sustainable environment friendly simulation model on poultry. The case industry is one of the biggest and reputed farms in Bangladesh. They are producing an average of 294,890 chicks per week having nearly 450 permanent employees. The total respondents were seven top executives from the case industry. The respondents nominated for open-ended questions relating to understands the required process based on their widespread knowledge and experiences. The in-depth interview long last for more than an hour for each respondent and information regarding production, process and waste management have discussed.

Secondary information related to industry productions of chicks, wastes, by-products collected from a company database. Later, researchers recalculate and assemble data in light of using in a simulation environment as a distribution along with time. Other secondary information was collected from different published documents such as referral books, journals and conference papers, statistical yearbooks and company record and reports. Industry database has been used to get the distribution pattern for various simulation artefacts. The reason behind using simulation is to perceive possible changes, prediction and its immediate effects on industry production (dynamics among the key variables), profitability and sustainable issues. Various trials will give an idea about the highest possible outcome and the optimality of industrial operation. This study has been used discrete event simulation method. Such event befalls at a specific instant in time and changes in the system (Robinson, [22]). The simulation package SIMUL8 (version 17) used to develop poultry model and conduct trivial analyses of existing poultry processes in order to investigate the research objectives. SIMUL8 is one of the prominent software that deals with discrete event simulation effectively.

\section{Sustainability}

World Commission on Environment and Development (WCED, [41]) declare sustainable development

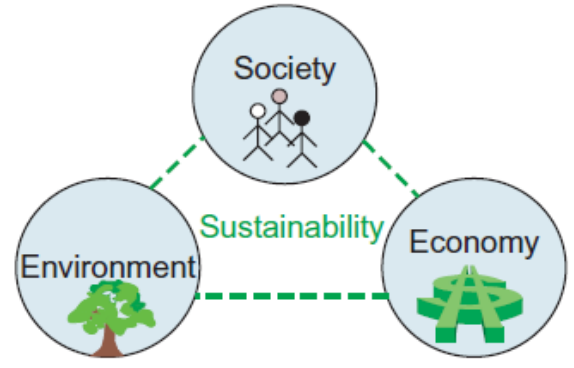

The three primary dimensions of sustainability.

Figure 1. Adopted from (Elkington, [12])

as "meeting the needs of the present without compromising the ability of future generations to meet their own needs." US Environmental Protection Agency defined sustainability as preserve or recover the social conditions and ecological capabilities that support them" (Sikdar [34]; Elkington [12]; Jennings [14]).

There is a growing interest in sustainability because of increasing population, unorganized Industrialization, decreasing standards of living, lessen natural resources, drastically global climate Change, escalation in the consumptions of the non-renewable resources and threat for biodiversity and ecosystems. Furthermore, sustainability comprises of three principals of environmental protection, economic growth, and societal equity. These are sometimes referred to as the "triple bottom line: people, planet, and profit" (Peacocka and Shermanb, [19]; Collins and Porras, [6]; Elkington, [12]). Shrivastava perceived it as the potential for reducing long-term risks associated with resource depletion, pollution and waste management" (Shrivastava, [33]). Bangladesh poultry industry does not uphold planned sustainable process based on social, economic and environment. For this, to achieve three factor successes in the poultry industry of Bangladesh, the researchers focused on the total poultry operation and split up into three phases of triple bottom line which is reflected similar with the sustainability.

\section{Supply Chain Process}

Supply chain is the process that starts from the early raw materials to the finished product linking across suppliers, users; within and outside a company (Cox et al., [8]). Supply chains also acquaintances among the internal and external partners of suppliers, carriers, third-party companies, and information systems providers. A key point in supply chain management is that the entire process viewed as one system (Lummus and Vokurka [17]). Kocabasoglu et al. integrates supply chain with the issues of disposal, recycling; reconditioning and remanufacturing of used and reject products (Kocabasoglu et al., [15]). Like- 
wise, the consideration of product design, process and produced of by-products, product life expansion, retrieve of product, and recovery processes at the end-of-life are amalgamated with supply chain process (Linton et al. [16]). The Bangladesh poultry industry has typical mainstream, forward and reverse supply chains that dealt with economic, social and environment issues. If appropriate techniques will be applied, poultry process can be turned into more sustainable to handle socioeconomic issues.

\section{Results and Discussion}

\section{Bangladesh Poultry}

Total population in Bangladesh is about 148.69 million at an annual growth rate of 1.1 percent and over $71.90 \%$ of the total population lives in the rural areas who are highly dependent on agricultural system. The contribution of the livestock sub-sector to GDP and the agriculture sector as a whole is currently $3.2 \%$ and 19\% respectively (Discovery Bangladesh [11]; Ruralpovertyportal [23]).

Poultry industry in Bangladesh has been developing rapidly since 1980 and 0.15 million poultry farmers and 6 million livelihoods directly depend on it (Rahman, [21]). The total population of poultry is 200-220 million and the daily waste produced from this industry is around 15-20 million tons (Bhuyian, [3]).

Among poultry species, the chicken population is dominant over others, at almost $90 \%$, followed by ducks (8\%) and a small number of quail, pigeons and geese (Das et al., [9]). In a condition, where the majority of the people are landless, under privileged, malnourished, uneducated and poor, poultry rearing can play a very important role for income generation, poverty eradication, women empowerment, nutrition, food security and the country's economical and development procedure (Shamsuddoha et al. [26]). Above literature represents, that poultry sector has tremendous opportunities to engage unemployed people, meet up protein deficiencies, make various sustainable by-products from its wastes, possibility of earning money, empowering and eliminating poverty from the country.

\section{Poultry Cycle}

The Bangladesh poultry cyclee starts mostly from Grand Parent (GP) tothe ultimate productss of meat and eggs. Pure Line and GGP (Great Grand Parent) breed are controlled by few poultry giant countries like USA, Canada, France, China etc. They used to supply such breed of grandparents in the different suitable countries through direct and indirect channels.

\section{Socio Economic Issues in Bangladesh}

The farming system has great potentialities to supplement the income of the farmers but also help in increasing the family labor employment throughout the year (Singh et al. [36,37]). The poultry industry is one of the major among livestock subsectors that committed to supply cheap sources of good quality nutritious animal protein to the nation (Shamsuddoha, [28]). Poultry farms eliminate unemployment problems and mostly grown up under private ownership having inadequate knowledge on sustainability (Shamsuddoha, [31]). Recently, unemployed young educated people have tried best to accept new technologies and concepts in their farming operation to achieve better profitability and sustainability (Shamsuddoha et al., [27]). Livestock plays an important part in household livelihoods and in some circumstances serve as a pathway out of poverty (Delgado et al., [10]; Perry and Grace, [20]). Bangladesh emphasize the efficient and effective use of these natural resources through modern technologies, which support alternative production processes and ensure maximum benefits by their efficient and sustainable utilization (Ahmed et al., [1]). Moreover, Poultry waste can generate 2,000 megawatts (MW) of power annually at a much lower cost (ThePoultry Site, [38]).

Figure 2 displays input-output process model based on observation method. Feed, medicine skilled-unskilled-semi-skilled labors, management decisions, egg production values, mortality rates, utilities such as electricity, gas, water, transportation and government decisions are major input of the poultry industry in Bangladesh. These elements are extremely important for this industry as all the economic successes depend on such issues. In the middle of the Figure 3, it shows the conventional process of this industry. The chain can be enhanced from raw material production to meat and eggs processed food via various kinds of farming and hatchery.

Table 1. Possible by-products from poultry wastes; Source: Interview

\begin{tabular}{|c|c|c|c|}
\hline Wastes & Generate & Industry & $\begin{array}{l}\text { Problems } \\
\text { mitigate }\end{array}$ \\
\hline \multirow{5}{*}{$\begin{array}{l}\text { Poultry } \\
\text { Droppings } \\
\text { /Litter }\end{array}$} & Fertilizers & Crop & $\begin{array}{l}\text { Economic, } \\
\text { Social and }\end{array}$ \\
\hline & & & Environ- \\
\hline & & & mental \\
\hline & Bio-gas & Power & Do \\
\hline & Charcoal & Power & Do \\
\hline $\begin{array}{l}\text { Feed Wastes, } \\
\text { Broken Eggs }\end{array}$ & Fish Feed & Fish & Do \\
\hline Feathers & Bed and Pillow & Pillow & Do \\
\hline $\begin{array}{l}\text { Unhatched } \\
\text { Eggs }\end{array}$ & $\begin{array}{l}\text { Cake and } \\
\text { Biscuits }\end{array}$ & Bakery & Do \\
\hline
\end{tabular}


There are different kind of poultry wastes: poultry droppings or litter (Burak et al., [4]), feathers (Shih, [32]), broken eggs and intestines (Burns and Stickney, [5]). Poultry litter can be the source of fertilizer (Gupta and Charles, [13]), bio gas (BBS, [2]), charcoal and fish feed (Burns and Stickney, [5]); feathers can be raw materials for the Bed industry (Shamsuddoha, [29]), broken eggs for the bakery and intestines for the fish farms (Shamsuddoha, [29]).

The process phase of the poultry industry is little bit complex rather it is shown in the above figure. This phase generates huge poultry wastes, typical poultry meat and eggs, culled birds, day old chicks and hatching eggs. Poultry wastes include litter, damaged eggs, rejected eggs, waste feed, poultry intestine and duck feed and feather (Shamsuddoha, [28]). All these can be used for further raw materials in different types of small scale manufacturing industry of bio-gas, pillow making, fertilizer, fish feed, bakery and artificial plants. Above mentioned processes can mitigate economic social and environmental problems in Bangladesh. In figure three which is less modified and tried to link economic, social and environmental issues to mitigate socioeconomic problems through poultry. This figure also consists of traditional or mainstream, forward and reverse supply chains of the poultry industry. All of the chains are mitigating socioeconomic problems of the society by generating economical values in terms of money, social values in terms of empowering woman, creating employments and business, reducing poverty etc. and environmental values by utilizing poultry wastes in to various kind of valuable by-products.

In the same figure, the researchers indicate the different output which classified into three different ways. In economic viewpoint, fresh meat, fresh eggs and processed meat are the main economic products for the poultry owner. Besides that, there are huge prospects to make by-products from poultry wastes those also very good economic viable by-products.

In social viewpoint, the Bangladeshi poultry industry is really rich which engages 6 million directly and around 15 million people indirectly (according to a government official, BBS [2]). This business is extending out in the remote areas which help to reduce poverty, diminish unemployment, and empower women.

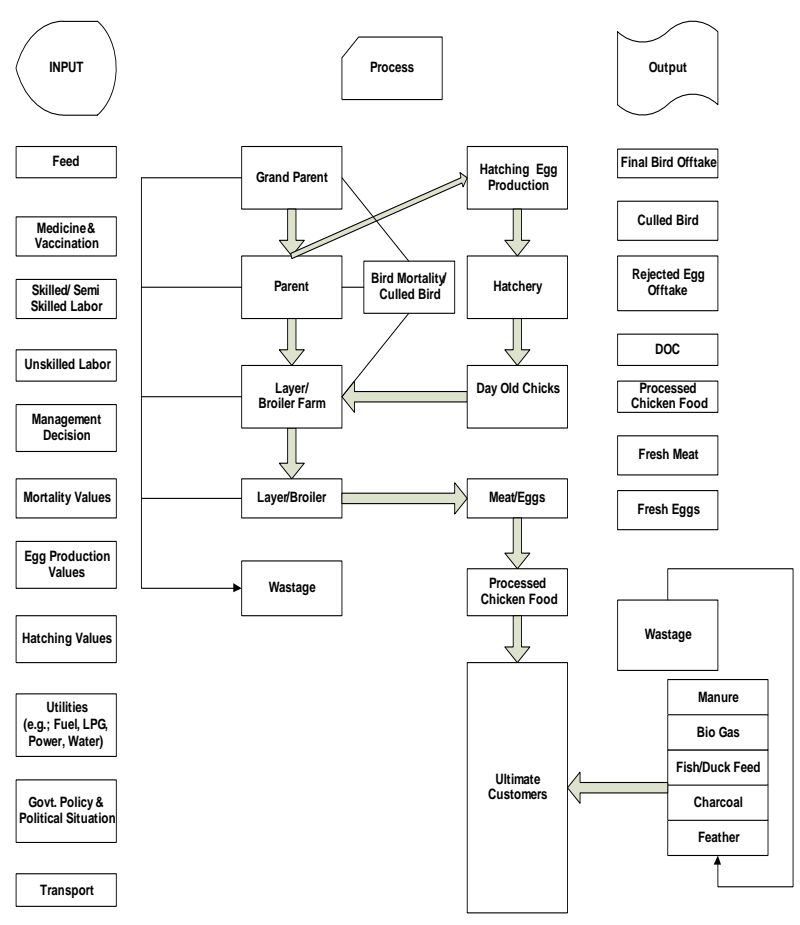

Figure 3. Input output poultry process model (Shamsuddoha, [28])

Finally, proper poultry waste management meeting up environmental side of sustainability that keeps the environment unchanged or intact and recycle or reuse the wastes economically.

Every single process of making by-products creates employments and empowered poor people. Poultry supply chain process model indicates social, environmental and economic benefits to achieve sustainability in a society.

\section{Bangladesh and Sustainability}

As an important sub-sector of livestock production, the poultry industry of Bangladesh plays a significant role in economic growth and employment creation (Shamsuddoha and Sohel, [25]). Poultry is also one of the alternative incomes generating activity for the rural poor people in Bangladesh (Shamsuddoha and Sohel, [24]).

The Poultry Industry, a fundamental part of animal production, is committed to supplying the nation with a cheap source of good quality nutritious animal protein in terms of meat and eggs (Shamsuddoha, [28]). 


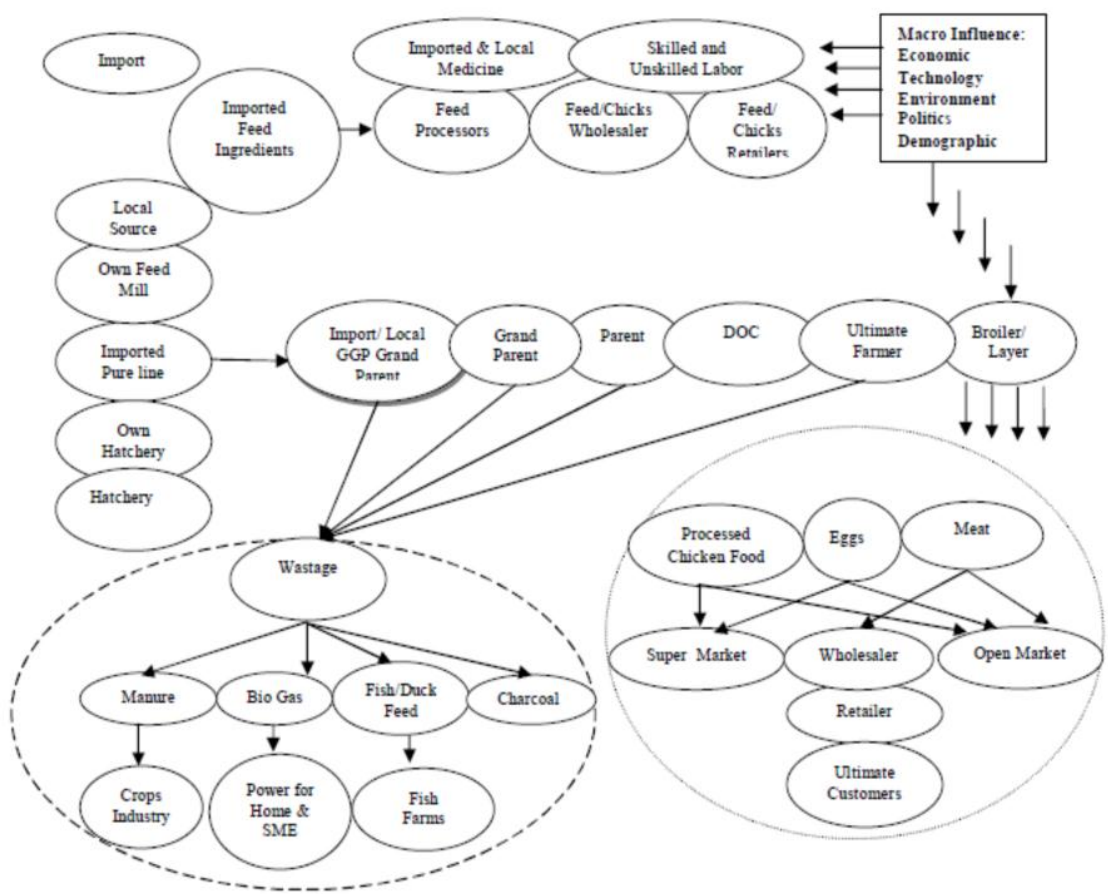

Figure 4. Proposed sustainable poultry supply chain process Model (Shamsuddoha [28])

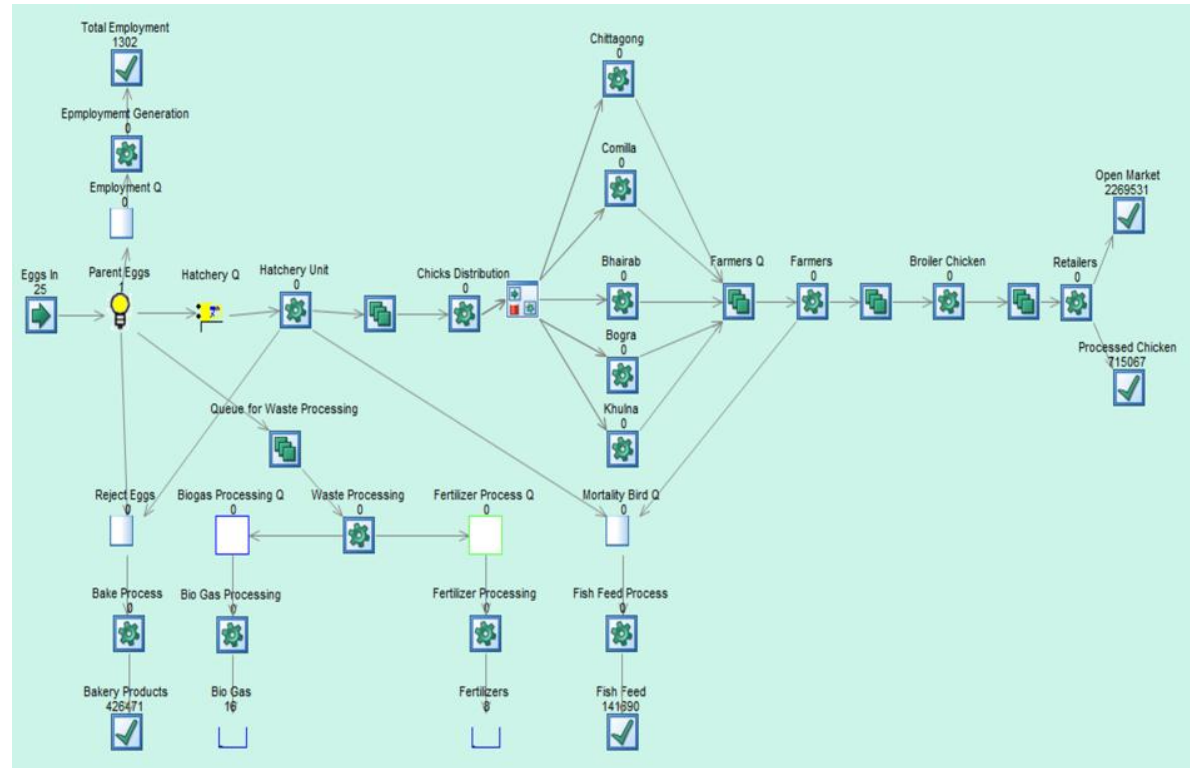

Figure 5. Sustainable poultry process supply chain in simulation environment (Shamsuddoha [30])

Table 2. KPI's of different objects in the model

\begin{tabular}{lrrrrrrr}
\hline Simulation Object & Run 1 & 2 & 3 & 4 & 5 & Average & $95 \%$ \\
\hline Bio gas & 1600 & 1900 & 1500 & 2000 & 1400 & 1680 & 2001.345 \\
Hatchery unit & 99.99 & 99.99 & 99.99 & 99.99 & 99.99 & 99.99 & 99.99 \\
Bakery products & 3.95 & 3.98 & 3.97 & 3.95 & 3.94 & 3.96 & 3.97 \\
Open market & 2269531 & 1711343 & 2848374 & 2288845 & 2139174 & 2251453 & 2756642 \\
Processed chicken & 715066.6 & 998696.6 & 427153.9 & 711573.1 & 848549.8 & 740208 & 1002102 \\
Bio gas & 591.11 & 726.67 & 514.44 & 781.11 & 646.67 & 652 & 783.53 \\
Fertilizers & 800 & 500 & 900 & 400 & 900 & 700 & 991.15 \\
Bakery products & 426471 & 716394.3 & 285320.3 & 428431.5 & 426115.4 & 456546.5 & 652308.9 \\
Total employment & 1302 & 1240 & 1373 & 1389 & 1314 & 1323.6 & 1397 \\
Fish feed & 141690.2 & 144815 & 143627 & 131337.9 & 141070.1 & 113782.7 & 192770.1 \\
\hline
\end{tabular}


This industry does significantly contribute to society in terms of economic, employment generation, and protein supply. Lots of poultry owners practice the triple bottom line framework of sustainability (social, economic and environmental) but not in an organized way (Shamsuddoha, [29]). Importantly, various by-products can be made from poultry wastages for home and industry use that is socially, economically and environmentally viable for Bangladesh perspective. This approach has the potentials of creating opportunities to establish small and medium enterprises (SME) that will reduce the unemployment rate and environmental disorder Sustainability must be implemented with the existing farm operation to achieve actual sustainable growth in their production and operation. Bangladesh poultry industry does not maintain a structured sustainable operation based on the triple bottom line of social, economic and environmental dimensions. To achieve these three factor successes in the poultry industry in Bangladesh, the researchers focused on the total poultry operation and split it up into three phases similar to sustainability concept as described above. Internationally, there are numerous large companies applying reverse supply chain concepts in considering the environment, customer satisfaction and so forth. These practices are not always non-profit oriented. In the poultry industry, there are few opportunities for product retrieval, return or reconditioning in the usual sense, as most chicken products are perishable (Shamsuddoha, [30]). However, there are immense opportunities to reuse or recycle poultry wastage. By reusing poultry wastage, Industries can make valuable products like fertilizers, biogas, pillows, charcoal, and bakery items. This kind of wastage conversion will help to maintain a sustainable environment (Shamsuddoha, [29]). Till now, sustainability, environment, forward and reverse supply chain have not received proper attention by the poultry stakeholders.

Poultry owners are currently integrating foreign technology and breed in their commercial farms for the sake of more productivity, profitability and achieving sustainability. Increasing the production level is generating more and more wastes, which can be used as raw material for a further by-product generation. This is why, poultry rearing along with reverse supply chain and environment concepts can play a noteworthy role in keeping the environment intact, empowering rural people, fulfilling nutritional needs, providing food and protein security (Shamsuddoha, [30]). Specifically, it helps to maintain standard quality of water, air and soil by not dumping poultry wastes in vacant land or riverside/water. In this way, poultry farmers can escape from common and rare poultry diseases that may protect their investments, farms, improve soil, water and air condition and restoring environmental damages.

\section{Simulation Model for Achieving Sustainability}

By observing case industry, the researchers develop a sustainable poultry supply chain model, which modeled using Simul8 - a simulation-modeling package. The model contains three different phases of mainstream, forward and reverse supply chain. The Mainstream component includes the general supply chain of the poultry industry that starts from parent (mother of chicks) and ends up with the finished product of meat and eggs. The forward supply chain component of this simulation model consists of distributor, farmers, and middlemen of processed and mature birds. This is the area where employment and other socio-economic benefits can be achieved based on the volume of bird transacted or reared. The reverse supply chain phase consists of managing poultry wastes of broken and un-hatched eggs, poultry litter, poultry feather etc. that is the main focal point of this research. This research develops a model to demonstrate and understand how poultry wastes provide the input (raw materials) to other by-product processing plant in the same industry. The simulation model is able to assess the volume of wastes that can use as the input of by-products. Industrialist can simulate the different distributions in various work centers like parents, hatchery, broiler and other processing centers to gain a better understanding of potential outcomes and to gain insight with respect to potential opportunities.

The researchers collected historic data from the case farm which provided parameters for the model and were used as an artifact in the Simul8 software. These artifacts were design as work entry, queue, work center and work and work exit. For example, "Eggs In" is a work entry where number of eggs input to hatch followed by distributors, farmers, middlemen and work exist of final products. This simulation was run for 90 days by splitting up into twice in a week entry method, i.e.; $90 / 3.5=25$ batch of work entered in this tenure. Total 37, 12,094 eggs simulate as throughput and broiler chicken as output. The model runs for around 13 weeks by ignoring seasonal variability and actual time. The data has been entered as time distribution in different work center, work entry and work queues. In the hatchery, after a certain period it produces day old chicks then goes to distributors for distribution to the different regions. After 25-35 days, the DOC becomes mature broiler chickens and is ready to be supplied to the open market, restaurants and processing centers. The rejected eggs, feathers, culled birds and litter are also generated after a certain interval. All these aspects are maintained in individual supply chains to produce different by-products. There are also different tech- 
nology and methods used to recycle, reuse and reduce the poultry wastes. Table two contains the KPI's of different objects in the model and these are standard reports in the simul8 software model. Such kinds of KPI's will denote profitability, optimality and viability of a poultry project whether it should carry on or need more modification or not to proceed.

In this study, the model was tested validity and reliability to compare to real life outputs/data. All the key variables are generating their output within the range of acceptability. The model was run through five different trials with the average results. Trial runs provide different results with variation which is important in the decision making and allows the decision maker to implement different strategies considering saving time, money and energy. Many different experiments and analysis can be conducted using the model environment.

\section{Results}

The results from the simulation model (Figure 3) are shown in the Table 2. Table 2 is presented different simulated KPIs (outputs) of variables like biogas, hatchery, bakery; Open market chicken sells, processed chicken and the likes. There are so many KPIs did not include in this discussion. However, if someone wants to perceive more, they can be able to perceive it. The capability of a simulation model is so vast so that it can be experimented at any stage of analysis to see what changed comes through the deviation of particular values. For example, eggs are given input through 'Eggs In' variable to the model where 25 batches injected based on time. Policy makers can be tested it by changing batch numbers with individual batch values. The trial and error will later provide optimum results to accept the possible processes. At the same time, the model is reflected on the number of employments created through the process. The more input will be given; the more employment and social benefits can be achieved. Again, more eggs processes will influence associated variables either positively or negatively based on relationship attached to the individual variable with preceding and succeeding variables. Moreover, it is impossible to model all the influences in the model, but the impacts are happening in the real-life. For instance, biogas production is involved to create more employments, empowerment for poor people and new entrepreneurs. Simultaneously, the poultry wastes processes are helping the environment to be protected. Like this, the poultry process extension will help to achieve socio-economic benefits, which ultimately, improve socio-economic conditions. The model initially replicates reality then it can be used for further extension and changes to see what benefits will be gained.

\section{Conclusion}

This paper can be applied to address a variety of recycling issues associated with sustainability concept. The model shows how the poultry industry can make various by-products from its wastage rather than being dumped in the river or on the vacant land. It also demonstrates that wastage can contribute towards the establishment of many small industries with the potentials of creating more opportunities to create employments, earn extra profit, eliminate poverty and protect environment. This is how the poultry industry can be more sustainable in comparing to present conditions. Obviously, this model will help the dynamic entrepreneurs to project their dream sustainable industry with multifaceted benefits for them and society respectively. The model can also be further extended or modified or tuned up in several directions of forward and reverse. For example, in practice, main operation and recycling matters hampers in the situation like heavy rainfall, flood, natural calamity similar to cyclones, droughts, poultry disease (bird-flue), alternative meat price, and some cultural influence etc. In these circumstances, the percentage of work flow shall be changed as per situation. Future research could focus on testing the entire process model and artefacts to understand the total industry operations, optimality and seasonal variety.

\section{References}

1. Ahmed, M. S., Ahmed, M. D., and Moni, N. N., Allocative Efficiency for the Sustainable Production Process of the Seafood Industry in Bangladesh, New Zealand Journal of Applied Business Research, 8, 2010, pp. 27-49.

2. BBS, Rural Poverty Portal 2010 [cited 29/03/ 2012]. Available from http://www.ruralpoverty portal.org/web/guest/country/statistics/tags/bang ladesh.

3. Bhuyian, M. F. A., Environment-friendly Poultry Waste Management: Prospect of Organic Fertilizer, Farm House: A Monthly Agribusiness Magazine, Dhaka Bangladesh, 2007, pp. 35-36.

4. Burak, A. H. T. C, Norman, E. S. Jr, and Mario R. E., Identification of Optimal Poultry Litter Biorefinery Location in Alabama through Minimization of Feedstock Transportation Cost, Environmental Progress 27, 2008.

5. Burns, P. R., and Stickney R. R., Growth of Tilapia Aurea in Ponds Receiving Poultry Wastes, Aquaculture, 20, 1980, pp. 117-121.

6. Collins, J., and Porras, J. I., Built to Last: Successful Habits of Visionary Companies, Harper Collins, 2002.

7. Corbett, C. J., and Kleindorfer, P. R., Environmental Management and Operations Manage- 
ment: Introduction to the Third Special Issue. Production and Operations Management, 12, 2003, pp. 287-289.

8. Cox, J. F., Blackstone, J. H., and Spencer, M. S., APICS Dictionary, 8th ed., Falls Church, VA.: American Production and Inventory Control Society, 1995.

9. Das, S. C., Chowdhury, S. D., Khatun, M. A., Nishibori, M., Isobe, N., and Yoshimura, Y., Poultry Production Profile and Expected Future Projection in Bangladesh. World's Poultry Science Journal, 64, 2008, pp. 99-118.

10. Delgado, C. L., Rosegrant, M. W., Steinfeld, H., Ehui, S. K., and Courbois C., Livestock to 2020: The Next Food Revolution. Markets and Structural Studies Division Discussion, Washington, DC: International Food Policy Research Institute, 1999.

11. Discovery Bangladesh, 2009.

12. Elkington, J., Towards the Sustainable Corporation: Win-win-win Business Strategies for Sustainable Development. California Management Review, 36, 1994, pp. 90-100.

13. Gupta, G., and Charles, S., Trace Elements in Soils Fertilized with Poultry Litter, Poultry Science, 78, 1999, pp. 1695-1698.

14. Jennings, P. D., Ecologically Sustainable Organizations: An Institutional Approach. The Academy of Management Review, 20, 1995, pp. 1015-1052.

15. Kocabasoglu, C., Prahinski, C., and Klassen, R. D., Linking Forward and Reverse Supply Chain Investments: The Role of Business Uncertainty. Journal of Operations Management, 25, 2007, pp. 1141-1160.

16. Linton, J. D., Robert, K., and Vaidyanathan, J., Sustainable Supply Chains: An Introduction, Journal of Operations Management, 25(6), 2007, pp. 1075-1082.

17. Lummus, R. R., and Robert J. V., Defining Supply Chain Management: A Historical Perspective and Practical Guidelines, Industrial Management \& Data Systems, 99(1), 1999, pp. 11-17.

18. March, S. T., and Smith, G., Design and Natural Science Research on Information Technology, Decision Support Systems, 15(4), 1995, pp. 251266.

19. Peacocka, C., and Shermanb, D. M., Sustainable Goat Production: Some Global Perspectives, Small Ruminant Research, 2010, pp. 70-80.

20. Perry, B. D., and Grace, D., The Impacts of Livestock Diseases and Their Control on Growth and Development Processes that are Pro-poor. Philosophical Transactions of the Royal Society $B, 364,2009$, pp. 2643-2655.

21. Rahman, M. A., Development of Convenient Composting Method Using Broiler Litter, Dept. of Animal Science. Mymensingh: Bangladesh Agricultural University, 2007.
22. Robinson, S., Simulation: The Practice of Model Development and Use, Wiley, 2004.

23. Ruralpoveryportal. Bangladesh Statistics. Available at: http://www.ruralpovertyportal.org/web/ guest/country/statistics/tags/Bangladesh, 2010.

24. Shamsuddoha, M., and Sohel, M. H., Problems and Prospects of Poultry Industry of Bangladesh: A Study on Some Selected Areas, The Chittagong University Journal of Business Administration, 19, 2004, pp. 273-286.

25. Shamsuddoha, M., and Sohel, M. H., Poultry Rearing: An Alternative Income Generating Activity for Rural Women Development of Bangladesh. The Chittagong University Journal of Business Administration, Bangladesh, 20, 2008, pp. 119-132.

26. Shamsuddoha, M., Klass, D., and Quaddus, M., A Simulation Supply Chain Model for a Sustainable and Environment Friendly Poultry Industry: Insights from Bangladesh. In: Voges $\mathrm{K}$ and Cavana B (eds) ANZAM 2011. Wellington, New Zealand: Australian and New Zealand Academy of Management (ANZAM), 2011, pp. 1-12.

27. Shamsuddoha, M., Quaddus, M., and Klass, D., Incorporating Reverse Supply Chain in the Poultry Process of Bangladesh Australian New Zealand Marketing Academy Conference 2011. Perth, Western Australia: ANZMAC.

28. Shamsuddoha, M., A Sustainable Supply Chain Process Model for Bangladeshi Poultry Industry. Doctoral Students Colloquium 2010. Perth, Australia: Curtin Business School, 2010, pp. 1-7.

29. Shamsuddoha, M., Applying Reverse Supply Chain in the Poultry Industry. In: Jefferson T, Shamsuddoha M and Young E (eds) Emerging Research Initiatives and Developments in Business: CGSB Research Forum 2011. Perth, Australia: Curtin University, 2011, pp. 159-167.

30. Shamsuddoha, M., Building a Conceptual Simulation Supply Chain Model for Sustainable Environment Friendly Poultry Industry. Sustainable Poultry Industry. Perth: Curtin University, 2011, pp. 1-12.

31. Shamsuddoha, M., Reverse Supply Chain Process as Environmental Sustainability in the Poultry Industry of Bangladesh. In: Goodison J (ed) Doctoral Colloquium 2011. Perth: Curtin Business School, Curtin University, 2011.

32. Shih, J. C. H., Recent Development in Poultry Waste Digestion and Feather Utilization: A Review, Poultry Science, 72, 1993, pp. 1617-1620.

33. Shrivastava, P., Hong, C. Zhang, Jianzhi, Li, and Allen W., Evaluating Obsolete Electronic Products for Disassembly, Material Recovery and Environmental Impact through a Decision Support System. Paper Read at Electronics and 
the Environment, 2005. Proceedings of the 2005 IEEE International Symposium.

34. Sikdar, S. K., Sustainable Development and Sustainability Metrics. AIChE Journal, 49, 2003, pp. 1928-1932.

35. Simon, H., The Sciences of the Artificial. Cambridge: MIT Press, 1969.

36. Singh, K. P, Singh, S. N., Kumar H, Kadian, V. S., and Saxena, S. S., Economic Analysis of Different Farming Systems Followed on Small and Marginal Land Holdings in Haryana. Haryana Journal of Agron, 9, 1993, pp. 122-125.

37. Singh, K. P, Singh, S. N., Kumar H, Kadian, V. S., and Saxena, S. S., Consistency in Income and Employment Generation in Various Farming Systems. Annals of Agricultural Resilance, 18, 1997,pp. 340-343.
38. ThePoultrySite, Poultry Litter can Ease Energy Crisis, The Daily Star. Dhaka Bangladesh: The Poultry Site, 2012.

39. Venable, J. R., A Framework for Design Science Research Activities in Information Resource Management Association Conference. Washington, DC, USA, 2006.

40. Venable, J. R., The Role of Theory and Theorising in Design Science Research. In 1st International Conference on Design Science (DESRIST), edited by A. Hevner and S. Chatterjee. Claremont, California, USA, 2006.

41. WCED, Our Common Future (The Brundtland Report), New York: Oxford University Press, 1987. (World Commission on Environment and Development).

42. Yin, R. K., Case Study Research: Design and Methods, Newbury Park, CA: Sage, 1994. 